\title{
Measurements of the dissolved inorganic carbon system and associated biogeochemical parameters in the Canadian Arctic, 1974-2009
}

\author{
K. E. Giesbrecht ${ }^{1, *}$, L. A. Miller ${ }^{1}$, M. Davelaar ${ }^{1}$, S. Zimmermann ${ }^{1}$, E. Carmack ${ }^{1}$, W. K. Johnson ${ }^{1}$, R. \\ W. Macdonald ${ }^{1}$, F. McLaughlin ${ }^{1}$, A. Mucci ${ }^{2}$, W. J. Williams ${ }^{1}$, C. S. Wong ${ }^{1}$, and M. Yamamoto-Kawai ${ }^{1, * *}$ \\ ${ }^{1}$ Institute of Ocean Sciences, Fisheries and Oceans Canada, Sidney, British Columbia, Canada \\ ${ }^{2}$ GEOTOP and Department of Earth and Planetary Sciences, McGill University, Montreal, Quebec, Canada \\ *now at: School of Earth and Ocean Sciences, University of Victoria, Victoria, British Columbia, Canada \\ ** now at: Research Centre for Advanced Science and Technology, Tokyo University of Marine Science and \\ Technology, Tokyo, Japan \\ Correspondence to: K. E. Giesbrecht (karinag@uvic.ca)
}

Received: 3 February 2013 - Published in Earth Syst. Sci. Data Discuss.: 15 June 2013

Revised: 1 February 2014 - Accepted: 3 February 2014 - Published: 20 March 2014

\begin{abstract}
We have assembled and conducted primary quality control on previously publicly unavailable water column measurements of the dissolved inorganic carbon system and associated biogeochemical parameters (oxygen, nutrients, etc.) made on 26 cruises in the subarctic and Arctic regions dating back to 1974. The measurements are primarily from the western side of the Canadian Arctic, but also include data that cover an area ranging from the North Pacific to the Gulf of St. Lawrence. The data were subjected to primary quality control (QC) to identify outliers and obvious errors. This data set incorporates over four thousand individual measurements of total inorganic carbon (TIC), alkalinity, and $\mathrm{pH}$ from the Canadian Arctic over a period of more than 30 years and provides an opportunity to increase our understanding of temporal changes in the inorganic carbon system in northern waters and the Arctic Ocean.

The data set is available for download on the CDIAC (Carbon Dioxide Information Analysis Center) website: http://cdiac.ornl.gov/ftp/oceans/IOS_Arctic_Database/(doi:10.3334/CDIAC/OTG.IOS_ARCT_CARBN).
\end{abstract}

\section{Data coverage and parameters measured}

Repository reference: doi:10.3334/CDIAC/OTG.IOS_ARCT_CARBN

Available at: http://cdiac.ornl.gov/ftp/oceans/IOS_Arctic_ Database/

Coverage: $48-83^{\circ} \mathrm{N} ; 174-307^{\circ} \mathrm{E}$

Location names: Gulf of Alaska; Bering, Beaufort, Chukchi, East Siberian and Labrador seas; Canadian Arctic Archipelago; Canada Basin; Baffin Bay; Gulf of St. Lawrence; Arctic Ocean Date/time start: 13 August 1974

Date/time end: 14 October 2009

\begin{tabular}{ll}
\hline $\begin{array}{l}\text { Data product } \\
\text { parameter name }\end{array}$ & Units \\
\hline $\begin{array}{l}\text { Cruise } \\
\text { Station name }\end{array}$ & \\
Nominal depth & meters \\
Cast no. & yyyy-mm-dd hh:mm \\
Date & decimal degrees \\
Latitude & decimal degrees \\
Longitude & meters \\
Cast depth & meters \\
$\begin{array}{l}\text { Water depth } \\
\text { sample no. }\end{array}$ & decibar \\
CTD pressure & ${ }^{\circ} \mathrm{C}$ \\
CTD temperature & \\
CTD salinity (practical & \\
salinity) & \\
CTD oxygen & micromole $\mathrm{kg}^{-1}$ \\
\hline
\end{tabular}




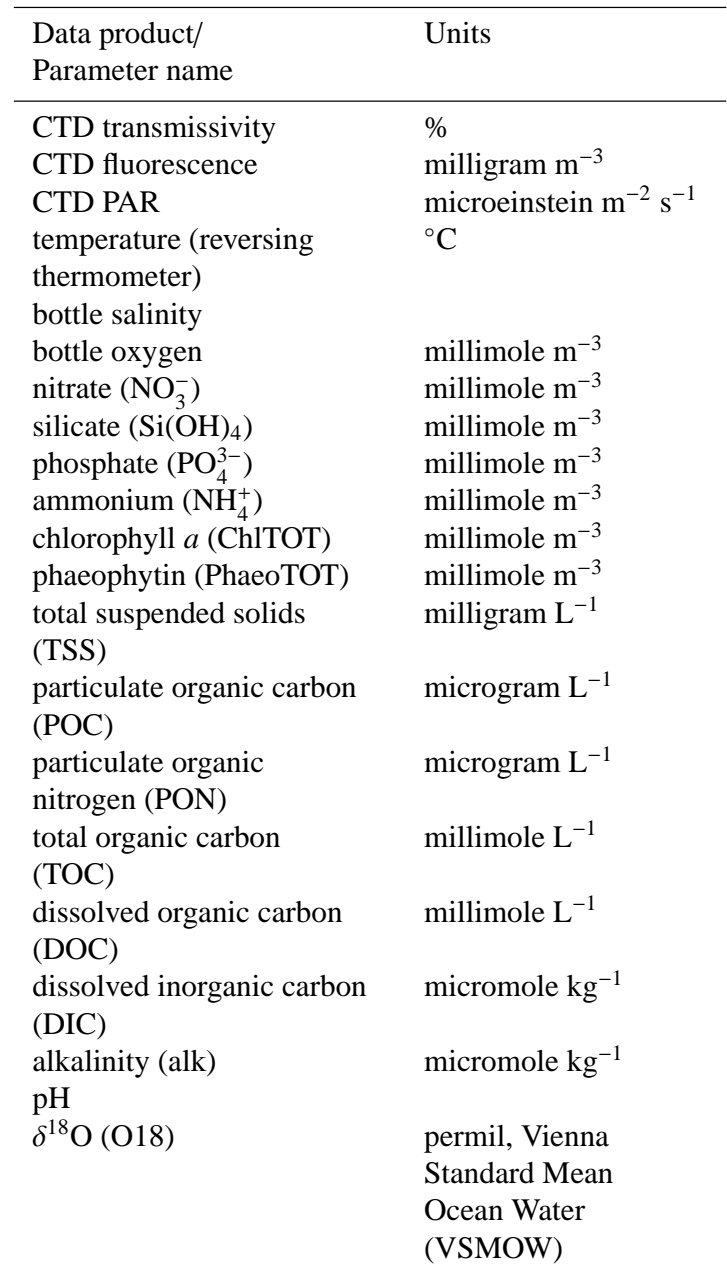

\section{Introduction}

The marine inorganic carbon system $\left(\mathrm{CO}_{2}, \mathrm{HCO}_{3}^{-}, \mathrm{CO}_{3}^{2-}\right.$, and $\left.\mathrm{CaCO}_{3}\right)$ is an essential component of the global carbon cycle and one of the most important buffer systems on the planet, controlling the acidity of seawater and the speciation of other weak acids and bases, as well as metals, in seawater (e.g., Byrne et al., 1988). This buffering system not only affects the chemistry of seawater, but also impacts biological systems, especially photosynthetic and calcareous organisms, and the atmosphere through air-sea exchange. The oceanic dissolved inorganic carbon reservoir is 50 times larger than the atmospheric $\mathrm{CO}_{2}$ reservoir (Raven and Falkowski, 1999). Given the constant exchange of gases between the two reservoirs through the air-sea interface and the relative size of the $\mathrm{CO}_{2}$ reservoirs, the oceanic reservoir ultimately controls the partial pressure of carbon dioxide in the atmosphere and thus plays a key role in regulating global temperatures. It is estimated that more than $30 \%$ of the anthropogenic $\mathrm{CO}_{2}$ emitted to the atmosphere since the onset of the Industrial Revolution in the mid-18th century has been absorbed by the ocean (Sabine et al., 2004). Increasing interest in the effects of anthropogenic $\mathrm{CO}_{2}$ in the atmosphere on the climate, the global carbon cycle, and ocean acidification has amplified the importance of high-quality time-series measurements of the marine inorganic carbon system, especially in regions like the Arctic, that are more sensitive and appear to respond faster to perturbations (Feely et al., 2009).

Scientists at the Institute of Ocean Sciences (IOS; Fisheries and Oceans Canada) and collaborators have collected seawater samples for analyses pertaining to the marine inorganic carbon system in the Arctic since 1974. By the early 1990s, collaboration with the Canadian coast guard enabled more frequent cruises in the western Canadian Arctic. In the first decade of the 21st century, collaboration with other Canadian, US, and other international scientists, and the intensive efforts deployed during the International Polar Year greatly increased the spatial and temporal coverage.

We initiated this data recovery project in response to the needs of an assessment conducted by the Arctic Monitoring and Assessment Programme of Arctic Ocean acidification (AMAP, 2013), that required the collation of a high-quality data set of all the available measurements of dissolved inorganic carbon and its associated parameters from the Arctic region. These data will also be included in the GLODAP2 data product compilation (Olsen et al., 2012).

\section{Data provenance}

This data set is a compilation of over 30 years of Canadian subarctic and Arctic inorganic carbon data collected and measured by scientists at IOS. Most of the inorganic carbon data included in this data set have previously been neither publicly available nor included in the IOS data archives. These data cover much of the Canadian Arctic region (Fig. 1), though most of the stations lay within the Beaufort and Chukchi seas and the Canada Basin. Sampling efforts in this region have increased over time (Figs. 2-4), and much of the data included in this data set originates from the year 2000 onward (Figs. 2d and 3). The seasonal coverage of the data has also increased over time (Fig. 3), though the majority of the data were collected in the summer months (July-September). The majority of the inorganic carbon system measurements included in this data set are for alkalinity (Fig. 4), especially from 2005 onwards.

This data set originates from several projects conducted during the period 1974-2009 (Table 1), including the Beaufort Sea Project (BSP, 1974-1975), the Northern Oil and Gas Action Program (NOGAP, 1986-1992), the Arctic Environmental Strategy (AES) Green Plan, Natural Resources Canada's (NRCan) Panel of Energy Research and Development (PERD) Climate Program and Ocean Climate Program (OCP) (1993-2000), the Canadian Arctic Shelf Exchange Study (CASES, 2002-2004), Canada's Three Oceans (C3O, 2007-2009), and the ongoing Canada-US-Japan collaboration Joint Ocean Ice Study (JOIS, 1997-2013). 
Table 1. List of the cruises included in the time-series data set and the associated information, including dates, references (cruise and data reports), and measured parameters.

\begin{tabular}{|c|c|c|c|}
\hline Cruise ID & Area $^{a}$ & Reference & Oceanographic parameters measured ${ }^{\mathrm{b}}$ \\
\hline $1975-74$ & 2 & Wong et al. (1976) & $\mathrm{CO}_{2}$ \\
\hline $1987-70$ & 2 & Macdonald et al. (1988b) & Chl, POM, O18, $\mathrm{CO}_{2}$ \\
\hline 1987-71 & 2 & Macdonald et al. (1988c) & Chl, POM, O18, $\mathrm{CO}_{2}$ \\
\hline $1990-70$ & 2 & Macdonald et al. (1991) & $\mathrm{Chl}, \mathrm{POM}, \mathrm{CO}_{2}$ \\
\hline $1995-26$ & 2,3 & Carmack et al. (1996) & Chl, POM, O18, $\mathrm{CO}_{2}$ \\
\hline $1996-31$ & 2 & McLaughlin (1996) & $\mathrm{CO}_{2}$ \\
\hline 1997-20 & 4 & McLaughlin et al. (2008) & Chl, O18, $\mathrm{CO}_{2}$ \\
\hline $2000-20$ & 1,2 & Hardenberg (2000) & $\mathrm{Chl}, \mathrm{O} 18, \mathrm{CO}_{2}$ \\
\hline $2000-22$ & 2,3 & McLaughlin et al. (2009a) & $\mathrm{Chl}, \mathrm{O} 18, \mathrm{CO}_{2}$ \\
\hline $2005-04$ & 2,3 & McLaughlin et al. (2010) & $\mathrm{Chl}, \mathrm{O} 18, \mathrm{CO}_{2}$ \\
\hline 2006-18 & 2 & McLaughlin et al. (2012) & $\mathrm{Chl}, \mathrm{POM}, \mathrm{O} 18, \mathrm{CO}_{2}$ \\
\hline $2006-43$ & 4 & McLaughlin et al. (2012) & $\mathrm{Chl}, \mathrm{O} 18, \mathrm{CO}_{2}$ \\
\hline $2007-19$ & $2-4$ & Zimmermann (2007) & $\mathrm{Chl}, \mathrm{POM}, \mathrm{CO}_{2}$ \\
\hline $2007-20$ & 2,3 & Zimmermann et al. (2007) & Chl, POM, O18, $\mathrm{CO}_{2}$ \\
\hline $2008-02$ & 2,3 & Vagle (2008) & $\mathrm{Chl}, \mathrm{O} 18, \mathrm{CO}_{2}$ \\
\hline $2008-30$ & 2,3 & Zimmermann et al. (2008) & $\mathrm{Chl}, \mathrm{O} 18, \mathrm{CO}_{2}$ \\
\hline 2009-06 & 1,2 & Vagle (2009) & $\mathrm{Chl}, \mathrm{CO}_{2}$ \\
\hline $2009-20$ & 2,3 & Zimmermann and McLaughlin (2009) & $\mathrm{Chl}, \mathrm{O} 18, \mathrm{CO}_{2}$ \\
\hline
\end{tabular}

${ }^{a}$ Areas are as follows: (1) Pacific sub-Arctic (Gulf of Alaska, Bering Strait), (2) western Arctic (Beaufort and Chukchi seas), (3) central Arctic (Canada Basin and Canadian Arctic Archipelago), (4) eastern Canadian Arctic (Baffin Bay, Hudson and Davis straits, Labrador Sea).

${ }^{\mathrm{b}}$ All cruises include measurements of $\mathrm{T}, \mathrm{S}, \mathrm{O}_{2}$ and macronutrients (nitrate, phosphate and silicate); Chl = chlorophyll $a$, POM = particulate organic matter (e.g., particulate organic carbon (POC) and nitrogen (PON), total suspended solids (TSS)), $\mathrm{O} 18=\delta^{18} \mathrm{O}, \mathrm{CO}_{2}=$ parameters of the inorganic carbon system (see Table 2 for details on which parameters).
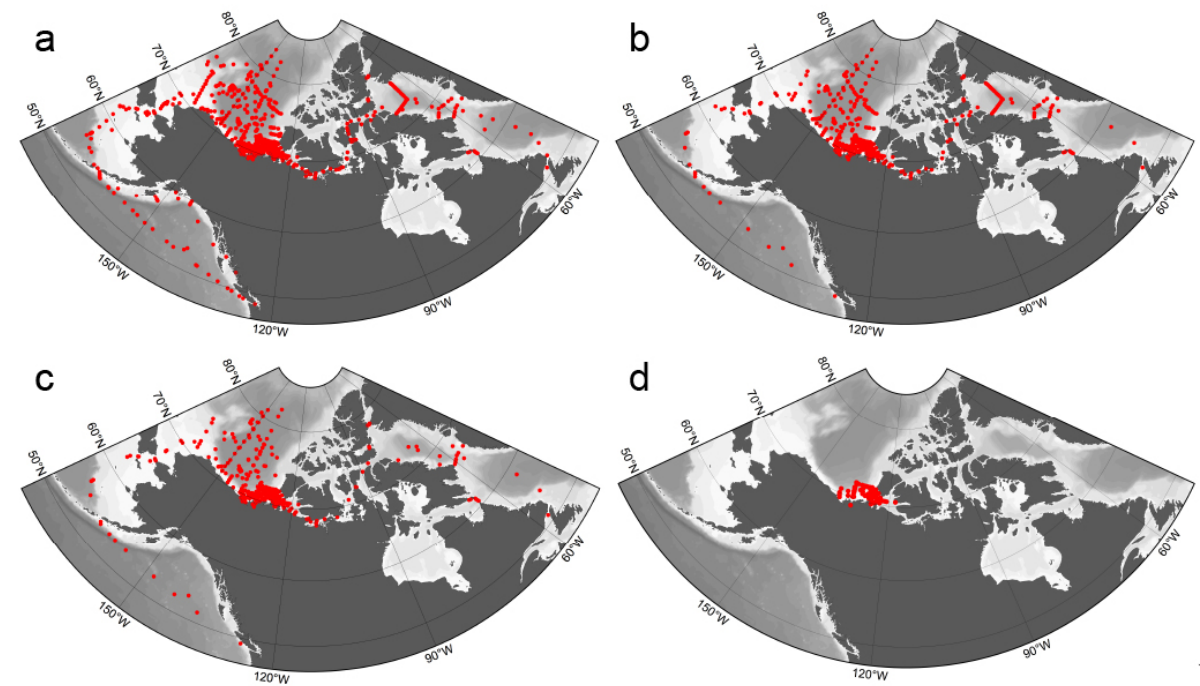

Figure 1. Map of (a) all stations included in the data set, and (b-d) all stations in the data set that include measurements of (b) alkalinity, (c) DIC, or (d) $\mathrm{pH}$. 


\subsection{Beaufort Sea Project (1974-1975)}

The BSP was initiated to improve our understanding of the Canadian Beaufort Shelf in the context of managing the exploration and potential development of offshore oil subsequent to Cabinet approval in principle for exploratory drilling in 1973. One component of the BSP provided chemical baseline data for the southern Beaufort Sea (Wong et al., 1976). Two cruises visited the region in the summers of 1974 (MV Theta) and 1975 (MV Pandora II). These cruises provided the first and only inorganic carbon measurements by IOS in this region prior to the late 1980s (Figs. 2a, 3-4). Niskin bottles outfitted with reversing thermometers were deployed to measure temperature and collect samples for salinity, dissolved oxygen concentration (by Winkler titration), and dissolved macronutrient concentrations (nitrate, silicate, and phosphate by spectrophotometry) at over 60 stations in the Beaufort Sea, with samples for DIC collected at 53 of those. Samples were collected following the standard protocol used at the time (see Appendix A) and stored at $4{ }^{\circ} \mathrm{C}$ prior to analysis.

Four samples collected from one station during a 1974 cruise were analyzed in 2001, while the remaining 233 viable samples were analyzed in 2013 , nearly forty years after collection, using contemporary methods (Fig. 5). A headspace correction (Dickson et al., 2007) was applied to the DIC measurements from the 1975 cruise as these samples had varying headspace volumes. To determine the headspace volume, samples were sorted into three classes according to a visual determination of the headspace, and a felt pen was used to mark the water level in the bottles prior to analysis. After analysis, headspace volume for each class was approximated as the mean of five gravimetric determinations of headspace volume for samples from each of the three classes. Though samples from these cruises were stored at IOS for nearly forty years, a test of IOS storage methods (see Sect. 3.2.1 below) indicated that the long-term storage of these samples had no effect on DIC or alkalinity.

\subsection{Northern Oil and Gas Action Program, subproject B.6 in the Canadian Beaufort Sea (1986-1992)}

NOGAP was funded by Indian and Northern Affairs Canada and included a major interdisciplinary study of the oceanography of the Canadian Beaufort Sea (NOGAP B.6: Macdonald et al., 1988a-c; 1991; Pearson et al., 1994). The main objective of NOGAP B.6 was to determine the transport and fate of materials (particularly petroleum hydrocarbons) on the Beaufort Shelf and the primary productivity of these coastal waters. Several summer cruises visited the Beaufort Sea over a period of six years.

Samples were collected for physical (i.e., temperature and salinity), chemical (i.e., dissolved oxygen, nitrate, silicate, phosphate, $\delta^{18} \mathrm{O}, \mathrm{Ba}$ (in 1992 (Falkner et al., 1994), and inorganic carbon), and biological (i.e., chlorophyll, partic- ulate organic carbon) parameters at over 60 stations. Most of the oceanographic data are included in the data reports cited above, although DIC was not. The DIC samples analyzed prior to 1988 were analyzed by gas chromatography (GC) (Fig. 5). All DIC samples analyzed after 1988 were analyzed by coulometry, either with a home-built extraction unit (1988-1989) or with a SOMMA (single-operator multimetabolic analyzer) system (1989-present) (Johnson et al., 1993). Pooled reproducibility values for these measurements are listed in Table 2.

\subsection{Western Arctic monitoring (1993-2000)}

The NRCan PERD Climate program supplied funding for five cruises to the western Arctic aboard Canadian coast guard ships (CCGS) - the Henry Larsen in 1993 (Macdonald et al., 1995), the Louis S. St.-Laurent in 1995 (Carmack et al., 1996) and 1996 (McLaughlin, 1996), and the Sir Wilfred Laurier (2000-20: Hardenberg, 2000; 2000-22: McLaughlin et al., 2009a) in 2000. The Arctic Environmental Strategy (AES) Green Plan provided additional funding for the cruises in 1993 and 1995. One of the main objectives of these early cruises was to measure water properties in Canada's western Arctic Ocean to investigate the effects of climate change and contaminants in this region.

Samples were collected at over 100 stations throughout the Beaufort, Chukchi, and East Siberian seas, the Canada Basin, and the Amundsen Gulf. The cruises in 2000 made up two legs of the annual transit of the CCGS Sir Wilfred Laurier from its southern port in Victoria, BC to the Arctic. The first leg (2000-20) was a collaboration between the Fisheries and Oceans Canada Ocean Climate Program (OCP), the Japan Marine Science and Technology Center (JAMSTEC), the University of Alaska Fairbanks (UAF), and the University of Tennessee (UTenn). The second leg (2000-22) was funded by PERD and focused on carbon sequestration using sediment traps in Amundsen Gulf. Parameters measured on all cruises from 1993 to 2000 include temperature, salinity, dissolved oxygen, nitrate, phosphate, silicate, and inorganic carbon. For the 1995 and 2000 cruises, the water column tracer $\delta^{18} \mathrm{O}$ was also measured. Most of the typical suite of oceanographic data is included in the data reports listed above, but measurements of the inorganic carbon system (DIC and alkalinity) were not. All DIC samples were analyzed at IOS using a SOMMA system (Fig. 5) (Johnson et al., 1993). Alkalinity samples were analyzed at IOS from the same sample collected for DIC using a closed-cell, automated potentiometric titration system (Millero et al., 1993). The precision of these methods for each cruise is listed in Table 2.

\subsection{Joint Ocean Ice Study (1997-ongoing)}

JOIS is the amalgamation of two collaborations: one between Fisheries and Oceans Canada (IOS) and the Japan Agency 

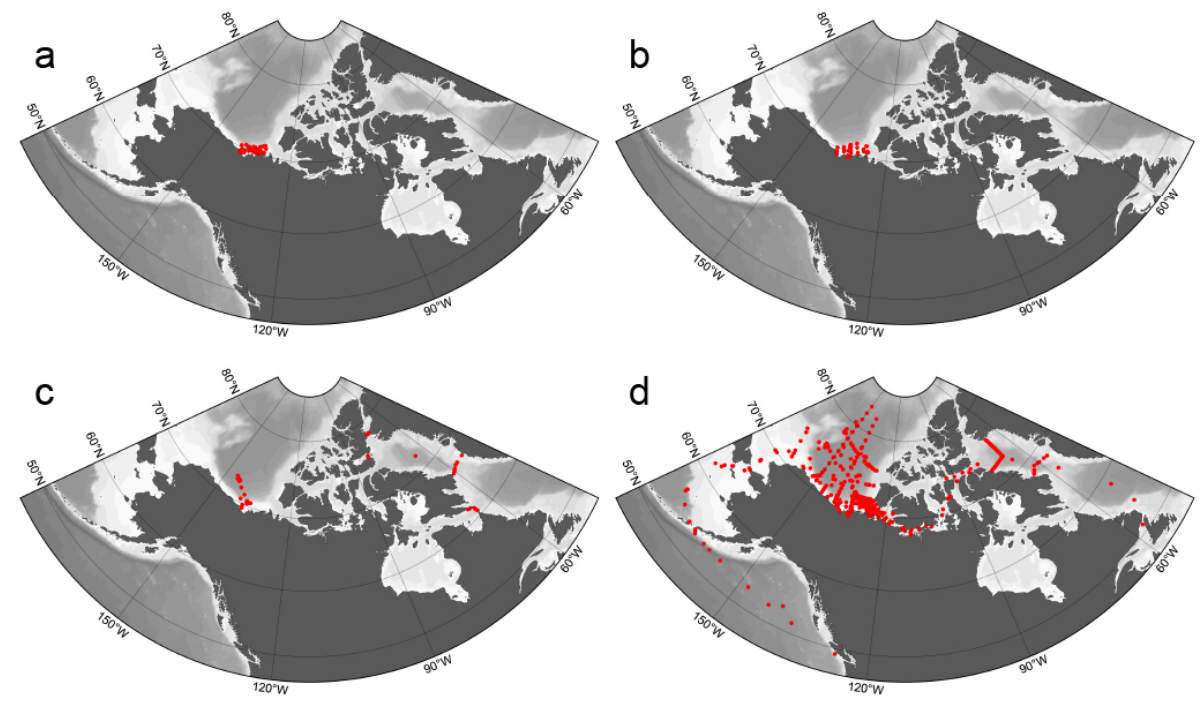

Figure 2. Map of all stations in the data set by decade: (a) 1970-1979, (b) 1980-1989, (c) 1990-1999, and (d) 2000-2009.

Table 2. List of the cruises included in the time-series data set and the associated information regarding their $\mathrm{CO}_{2}$ data. A question mark indicates information that is unavailable.

\begin{tabular}{|c|c|c|c|c|c|c|c|}
\hline Cruise ID & $\begin{array}{l}\text { Date } \\
\text { (yyyy-mm) }\end{array}$ & Area $^{\mathrm{a}}$ & $\begin{array}{l}\text { Number of } \\
\text { stations }^{\mathrm{b}}\end{array}$ & $\begin{array}{l}\text { Inorganic carbon } \\
\text { parameter(s) measured }\end{array}$ & $\mathrm{CRM}^{\mathrm{c}}$ & $\begin{array}{r}\text { Pooled SD. }{ }^{\mathrm{d}} \\
\left(\mu \mathrm{mol} \mathrm{kg}{ }^{-1}\right)\end{array}$ & $\begin{array}{l}\text { DIC method } \\
\text { (Fig. 5) }\end{array}$ \\
\hline $1974-70$ & $1974-08$ & 2 & 24 & DIC, $A_{\mathrm{T}}$ & yes & - & coulometry \\
\hline $1975-74$ & $1975-08$ & 2 & 38 & DIC, $A_{\mathrm{T}}$ & yes & - & coulometry \\
\hline 1986-71 & 1986-09 & 2 & 42 & DIC & no & 3.2 & GC \\
\hline $1987-70$ & 1987-04 & 2 & 32 & DIC & no & 3.2 & $\mathrm{GC}$ \\
\hline 1987-71 & $1987-08$ & 2 & 64 & DIC & no & 3.2 & $\mathrm{GC}$ \\
\hline $1990-70$ & 1990-09 & 2 & 32 & DIC & ? & 0.9 & coulometry \\
\hline 1992-16 & 1992-09 & 2 & 15 & DIC & yes & - & coulometry \\
\hline $1993-24$ & 1993-09 & 2 & 102 & DIC, $A_{\mathrm{T}}$ & yes & $0.3,0.6$ & coulometry \\
\hline 1995-26 & 1995-08 & 2,3 & 45 & DIC, $A_{\mathrm{T}}$ & yes & $1.3,1.2$ & coulometry \\
\hline 1996-31 & 1996-09 & 2 & 12 & DIC, $A_{\mathrm{T}}$ & yes & - & coulometry \\
\hline 1997-20 & 1997-09 & 4 & 24 & DIC, $A_{\mathrm{T}}$ & yes & $2.4,2.8$ & coulometry \\
\hline $2000-20$ & $2000-07$ & 1,2 & 55 & DIC, $A_{\mathrm{T}}$ & yes & - & coulometry \\
\hline $2000-22$ & 2000-09 & 2,3 & 30 & DIC, $A_{\mathrm{T}}$ & yes & - & coulometry \\
\hline CASES2002 & 2002-09 & 3,4 & 65 & DIC, $A_{\mathrm{T}}$ & yes & $1.4,2.4$ & coulometry \\
\hline $2002-23$ & $2002-08$ & 2 & 39 & DIC, $A_{\mathrm{T}}$ & yes & $1.5,1.9$ & coulometry \\
\hline 2003-21 & 2003-08 & 3 & 39 & DIC, $A_{\mathrm{T}}$ & yes & - & coulometry \\
\hline CASES2003 & $2003-09$ to $2004-08$ & 3,4 & 614 & DIC, $A_{\mathrm{T}}, \mathrm{pH}$ & yes & $2.6,3.3,0.005$ & coulometry \\
\hline 2005-04 & $2005-08$ & 2,3 & 92 & DIC, $A_{\mathrm{T}}$ & yes & $1.5,1.6$ & coulometry \\
\hline 2006-18 & 2006-08 & 2 & 125 & DIC, $A_{\mathrm{T}}$ & yes & $1.3,1.4$ & coulometry \\
\hline $2006-43$ & 2006-09 & 4 & 25 & DIC, $A_{\mathrm{T}}$ & yes & - & coulometry \\
\hline 2007-19 & 2007-07 & $2-4$ & 58 & DIC, $A_{\mathrm{T}}$ & yes & - & coulometry \\
\hline 2007-20 & 2007-08 & 2,3 & 103 & DIC, $A_{\mathrm{T}}$ & yes & $3.0,1.8$ & coulometry \\
\hline $2008-02$ & $2008-07$ & 2,3 & 74 & DIC, $A_{\mathrm{T}}$ & yes & - & coulometry \\
\hline $2008-30$ & 2008-08 & 2,3 & 32 & DIC, $A_{\mathrm{T}}$ & yes & $1.6,2.4$ & coulometry \\
\hline 2009-06 & 2009-07 & 1,2 & 28 & DIC, $A_{\mathrm{T}}$ & yes & $0.6,0.5$ & coulometry \\
\hline 2009-20 & 2009-09 & 2,3 & 53 & DIC, $A_{\mathrm{T}}$ & yes & $0.8,1.5$ & coulometry \\
\hline
\end{tabular}

${ }^{a}$ Areas are as follows: (1) Pacific sub-Arctic (Gulf of Alaska, Bering Strait), (2) western Arctic (Beaufort and Chukchi seas), (3) central Arctic (Canada Basin and Canadian Arctic Archipelago), (4) eastern Canadian Arctic (Baffin Bay, Hudson and Davis Straits, Labrador Sea).

b Number of stations in the final data set.

${ }^{\mathrm{c}}$ Certified reference materials were used to calibrate analyses.

d Pooled standard deviation of duplicate TIC, $A_{\mathrm{T}}$ and/or $\mathrm{pH}$ samples. 


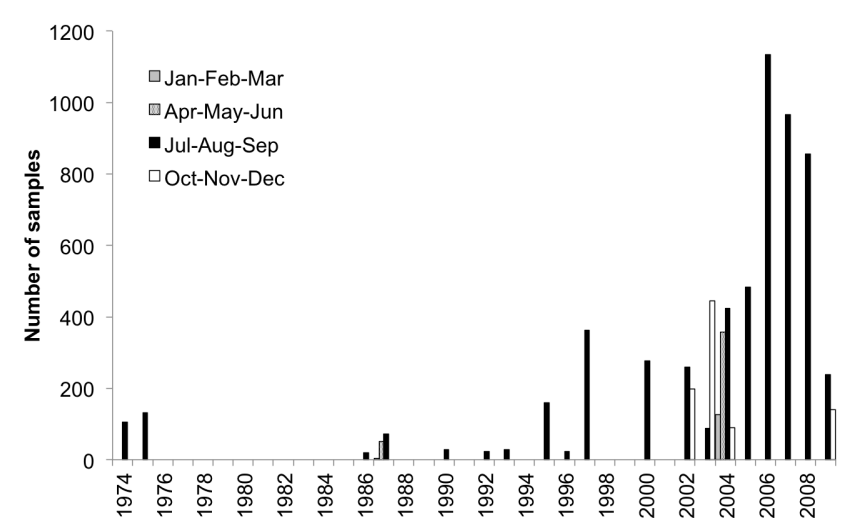

Figure 3. Distribution of carbon system measurements (alkalinity, $\mathrm{DIC}$ and/or $\mathrm{pH}$ ) included in the data set by year, categorized into three-month spans.

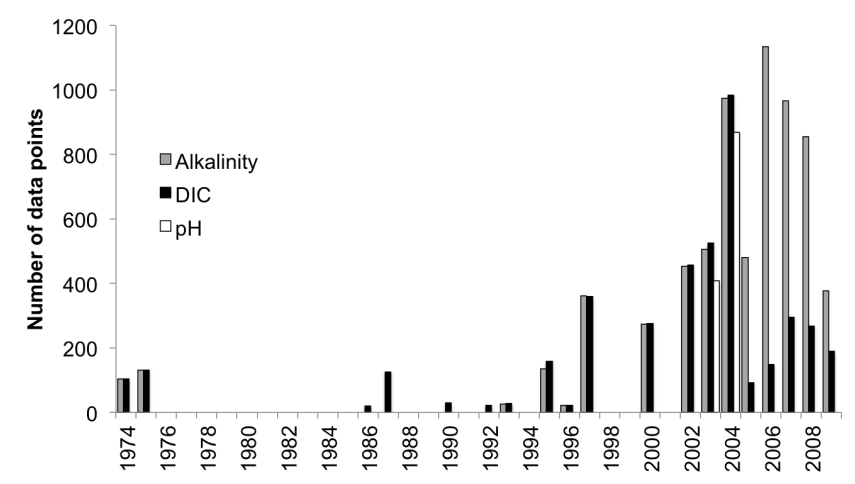

Figure 4. Distribution of alkalinity, DIC and $\mathrm{pH}$ data points included in the data set by year.

for Marine-Earth Science and Technology (JAMSTEC) that began in the 1990s; and the second between Fisheries and Oceans Canada (IOS) and various US scientists funded by the National Science Foundation. In 1997, the Canada-US collaboration, in support of the year-long ice-drift SHEBA (Surface Heat Budget of the Arctic Ocean) program, enabled oceanographic surveys to be conducted in Davis Strait, Baffin Bay, the Canadian Arctic Archipelago and the Canada Basin. In 2003, a 10-year collaboration called the Beaufort Gyre Exploration Project (BGEP) began with scientists from the Woods Hole Oceanographic Institution. This program focused on the effects of climate variability and the changing properties of the Pacific and Atlantic waters within the Arctic Ocean, specifically in the southern Canada Basin (including the Beaufort Sea). These cruises were conducted yearly onboard the CCGS Louis S. St.-Laurent in late summer and fall. In addition to the suite of typical oceanographic parameters measured (temperature, salinity, dissolved oxygen, nitrate, phosphate, silicate, and inorganic carbon), samples were also collected for water column tracers (i.e., barium, CFCs (chlorofluorocarbons) and $\delta^{18} \mathrm{O}$ ) and radionuclides (i.e., ${ }^{137} \mathrm{Cs}$,

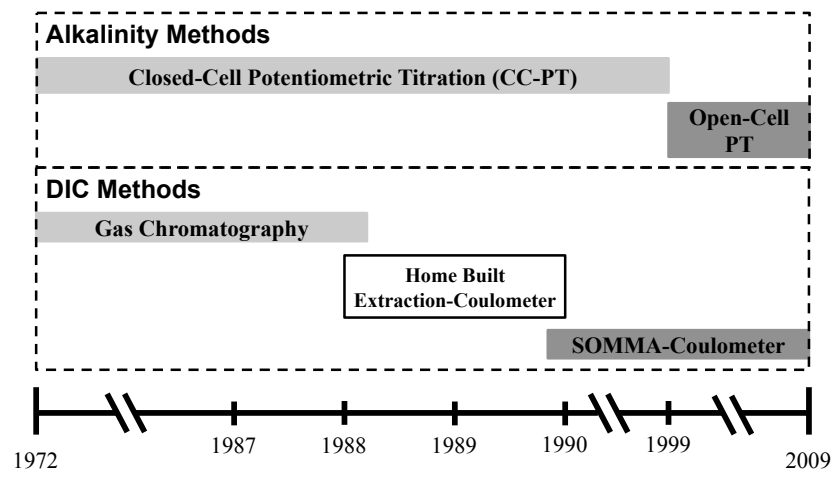

Figure 5. Timeline of the different methods used by IOS for DIC and alkalinity analyses. See Sect. 3.2 for details.

${ }^{129}$ I) as well as biological samples ranging from microplankton to zooplankton.

Over 1900 samples for DIC and 4000 samples for total alkalinity were collected and analyzed as part of the program. Samples for DIC were analyzed coulometrically using the SOMMA system at IOS (Fig. 5). Samples for total alkalinity were analyzed by potentiometric titration (closed-cell before 1999 and open-cell thereafter, see Fig. 5) either onboard or at IOS. See Table 2 for a cruise-specific listing of the measurement precisions for each of these cruises. These data are available on the BGEP website and methods are described in the data reports (Table 1). The BGEP collaboration is now funded to 2018.

\subsection{Canadian Arctic Shelf Exchange Study (2002-2004)}

CASES was a comprehensive, interdisciplinary ecosystem study of the Cape Bathurst Polynya, funded by Canada's Natural Sciences and Engineering Research Council, Fisheries and Oceans Canada, and the US National Science Foundation. The project included a short preliminary cruise in September and October of 2002, followed by a major overwintering expedition that continuously sampled the area for 50 weeks, from September 2003 to August 2004 (Fortier and Cochran, 2008).

The inorganic carbon system was over-determined, with DIC, total alkalinity $\left(A_{\mathrm{T}}\right)$, and $\mathrm{pH}$ (total proton scale) analyzed on most of the nearly 1800 samples collected during the overwintering expedition. Dissolved inorganic carbon was determined coulometrically, total alkalinity by potentiometric titration, and $\mathrm{pH}$ spectrophotometrically; detailed sampling and analytical procedures were described by Mucci et al. (2010). Table 2 lists the measurement precision for each of these methods.

\subsection{Canada's Three Oceans (1998-present)}

The aim of $\mathrm{C} 3 \mathrm{O}$ was to provide a view of the impacts of climate variability on the sub-arctic and Arctic water circulation 
and on the associated ecosystems. The program began in 1998 with funding by Fisheries and Oceans Canada and the National Science Foundation (NSF). This funding was enhanced during the International Polar Year (IPY), 2007 to 2009, with Canadian IPY funding. Measurements were made at the start of each summer from two coast guard ships, the CCGS Sir Wilfrid Laurier in the Pacific and the CCGS Louis S. St.-Laurent in the Atlantic, during their annual transit from their southern ports, Victoria and Halifax respectively, to the Arctic. Shipboard data collection included physical, biological, geochemical and benthic sampling. The sampling areas covered by the CCGS Sir Wilfrid Laurier were typically in the shelf regions of the Bering and Chukchi seas, and during 2008 this was expanded to the shelf and shelf-break along the Beaufort Sea, as well as the Amundsen Gulf region of the Canadian Arctic Archipelago. From the CCGS Louis S. St.Laurent, sampling areas included the Labrador Sea, Baffin Bay, and a transect through the Canadian Arctic Archipelago.

Over 200 samples for DIC and total alkalinity were collected and analyzed as part of the $\mathrm{C} 3 \mathrm{O}$ program. Samples for DIC were analyzed coulometrically using the SOMMA system at IOS (Fig. 5). Samples for total alkalinity were analyzed by potentiometric titration (closed-cell before 1999 and open-cell thereafter, see Fig. 5) at IOS. See Table 2 for a cruise-specific listing of the measurement precision for each of these methods.

\section{Methods and quality control procedures}

\subsection{Physical, chemical and biological oceanographic measurements}

Details on the collection and analysis of these parameters are presented with the associated data and technical reports for each project (Table 1). Therefore, we only discuss measurements pertaining to the dissolved inorganic carbon system. Chemical measurements of dissolved oxygen, nitrate, phosphate, silicate, and $\delta^{18} \mathrm{O}$ are also included in this data set, but with no additional quality control, as these data have been previously assessed and archived. Biological measurements, such as chlorophyll and particulate organic carbon and nitrogen, were also included when available, though again, with no additional quality control.

\subsection{Inorganic carbon system parameters}

\subsubsection{Sampling and sample storage}

Sampling generally followed standard protocols (i.e., DOE, 1994; Dickson et al., 2007). Samples were stored at a stable temperature, generally about $4{ }^{\circ} \mathrm{C}$, until analysis either at sea or on shore. Alkalinity and DIC were usually measured from the same sample. A dilution correction factor was applied to samples when a mercuric chloride solution was used (after 1994). Little published information is available about the methods of inorganic carbon sample collection and storage for samples collected prior to 1993, though the data reports state that samples were collected. The sampling protocol used before DOE (1994) is transcribed in Appendix A. Sampling according to this protocol used powdered mercuric chloride, and so no correction for dilution was applied to samples collected prior to 1993 .

To confirm the integrity of samples stored long-term at IOS, archived deep-water (1000-3000 m) samples collected at Station Papa $\left(50^{\circ} \mathrm{N} 145^{\circ} \mathrm{W}\right)$ in 1976 were analyzed for DIC and alkalinity and compared to recently collected samples from the same depths at Station Papa (sampled between 2003 and 2010) (Table 3). Station Papa's data make up a long-running deep ocean time-series located in the subarctic northeastern Pacific, a region where deep-water $(>800 \mathrm{~m})$ DIC and alkalinity are assumed to be virtually constant on decadal time scales (Byrne et al., 2010). Thus, any differences between the deep-water DIC and alkalinity values measured in the samples that have been stored for several decades and more recent samples would indicate a bias or error resulting from the storage procedures. There were no significant differences (Student's $t$ test) between the 1976 and more recent samples for both DIC and alkalinity. No systematic bias was observed between samples from these two time periods. These results confirm the viability of long-term storage in the refrigerated sample archive at IOS for seawater DIC and alkalinity samples, for up to forty years.

\subsubsection{Dissolved inorganic carbon (DIC)}

Samples collected for dissolved inorganic carbon analysis were not filtered prior to analysis; thus, measurements are of total inorganic carbon (TIC), which includes the particulate (PIC) and dissolved (DIC) fractions. Nevertheless, for all practical purposes, TIC is equivalent to DIC in seawater samples. Two different methods have been used to determine the dissolved inorganic carbon content of seawater samples at IOS: gas chromatography and coulometry. Unfortunately, there is little information regarding the analyses prior to 1992 , especially those samples from the early NOGAP cruises (1986-71, 1987-70, and 1987-71). The gas chromatographic method was used far less often than the coulometric method and appears to have been limited to samples from three Arctic cruises in the late 1980s. The coulometric method has been used by IOS to measure DIC samples since early 1988 and has been the only method used since early 1989. Figure 5 gives a timeline of the overlap of these different methods. Details of each of these methods are outlined below. In addition, a previously unpublished intercomparison study between these methods was conducted at IOS during the transition to the coulometric-based DIC measurements. The results of that comparison are reviewed below.

Samples collected on the early NOGAP cruises (1986-71, 1987-70 and 1987-71) were analyzed by gas chromatography. Little information is available regarding the analysis 
Table 3. Alkalinity and DIC measurements of deep-water samples collected at Station Papa in 1976 and between 2003 and 2010 and stored at IOS.

\begin{tabular}{lll|ll}
\hline \multirow{2}{*}{ Depth } & \multicolumn{2}{c|}{ Station Papa (1976) } & \multicolumn{2}{c}{ Station Papa (2003-2010) } \\
\cline { 2 - 5 } & $\begin{array}{l}\text { DIC } \\
\left(\mu \mathrm{mol} \mathrm{kg}^{-1}\right)\end{array}$ & $\begin{array}{l}\text { Alkalinity } \\
\left.(\mu \mathrm{mol} \mathrm{kg})^{-1}\right)\end{array}$ & $\begin{array}{l}\text { DIC } \\
\left(\mu \mathrm{mol} \mathrm{kg}^{-1}\right)\end{array}$ & $\begin{array}{l}\text { Alkalinity } \\
\left.(\mu \mathrm{mol} \mathrm{kg})^{-1}\right)\end{array}$ \\
\hline $1000 \mathrm{~m}$ & 2385.01 & 2375.45 & $\begin{array}{l}2379.66 \pm 5.56 \\
(n=12)\end{array}$ & $\begin{array}{l}2376.43 \pm 7.78 \\
(n=12)\end{array}$ \\
\hline $2000 \mathrm{~m}$ & $\begin{array}{l}2383.13 \pm 2.43 \\
(n=2)\end{array}$ & $\begin{array}{l}2405.40 \pm 0.80 \\
(n=2)\end{array}$ & $\begin{array}{l}2381.67 \pm 2.87 \\
(n=13)\end{array}$ & $\begin{array}{l}2417.03 \pm 9.05 \\
(n=13)\end{array}$ \\
\hline $3000 \mathrm{~m}$ & $\begin{array}{l}2360.10 \pm 4.23 \\
(n=4)\end{array}$ & $\begin{array}{l}2424.18 \pm 5.84 \\
(n=4)\end{array}$ & $\begin{array}{l}2356.01 \pm 4.78 \\
(n=13)\end{array}$ & $\begin{array}{l}2426.48 \pm 6.00 \\
(n=13)\end{array}$ \\
\hline
\end{tabular}

of these specific samples, but it is assumed that the method used was the same as that described in an operating procedure used at the time by the Centre for Ocean Climatic Chemistry at IOS, and that method is summarized here. The method was based on the technique described by Swinnerton et al. (1962) and Weiss and Craig (1973). Briefly, the sample was drawn into a $3 \mathrm{~mL}$ stainless steel loop, and the calibrated volume was injected into a sparging cell containing concentrated phosphoric acid to quantitatively extract the inorganic carbon as $\mathrm{CO}_{2}$. The valve controlling sample introduction to the sparging chamber was flushed repeatedly with a $\mathrm{CO}_{2}$-free saline solution between samples to reduce carryover. The loop was temperature-controlled in an ice bath at $0{ }^{\circ} \mathrm{C}$ to maintain accurate volume and to limit degassing due to warming. The gas evolved from the sparging cell was carried by a stream of purified helium through a cold trap at -55 to $-60{ }^{\circ} \mathrm{C}$ and through a silica gel column to separate $\mathrm{CO}_{2}$ from $\mathrm{H}_{2} \mathrm{O}$ and other gases. Carbon dioxide was quantified with a thermal conductivity detector using peak area integration. Conversion to units of $\mu \mathrm{mol} \mathrm{kg}{ }^{-1}$ was based on density calculated from the sample salinity and an analysis temperature of $0{ }^{\circ} \mathrm{C}$. The gas chromatograph was calibrated using a standard $\mathrm{Na}_{2} \mathrm{CO}_{3}$ solution introduced through the same sampling loop.

The first coulometer was delivered at IOS in mid-1987. This instrument was attached to an in-house built extraction unit similar to that described by Johnson et al. (1985). This early system was used for DIC analyses from early 1988 until late 1989 with standardization by solid $\mathrm{CaCO}_{3}$ or $\mathrm{Na}_{2} \mathrm{CO}_{3}$ salts, as described by Wong (1970). After 1988, all DIC analyses were conducted coulometrically (Fig. 5). Samples analyzed after late 1989 were analyzed with SOMMA systems (Johnson et al., 1993). Over time, the accuracy of the coulometric DIC analyses was, at first, confirmed by analyses of weighed quantities of $\mathrm{Na}_{2} \mathrm{CO}_{3}$ salts, then by daily analysis of seawater standards prepared at IOS and calibrated against $\mathrm{Na}_{2} \mathrm{CO}_{3}$ salts, and ultimately by daily analyses of certified reference materials (CRMs) provided by Andrew Dickson (Scripps Institute of Oceanography) and IOS-prepared sec- ondary standards calibrated against CRMs. The precision of the coulometric analyses, based on the difference between sample duplicates, has generally been about $\pm 1 \mu \mathrm{mol} \mathrm{kg} \mathrm{kg}^{-1}$ $(0.05 \%)$.

The Centre for Ocean Climate Chemistry at IOS conducted an intercalibration study between the gas chromatographic and coulometric methods in the late 1980s. Samples of varying salinities ( 8 to 38 ) were analyzed for their total $\mathrm{CO}_{2}$ content using both gas chromatography and coulometry. Each system was standardized using $\mathrm{Na}_{2} \mathrm{CO}_{3}$ salts, as described by Wong (1970). Replicate analyses of the same samples revealed that the precision of the coulometric method (mean SD: $1.80 \mu \mathrm{mol} \mathrm{kg} \mathrm{kg}^{-1}, n=4$ ) was slightly better than that of the gas chromatographic method (mean SD: $\left.2.83 \mu \mathrm{mol} \mathrm{kg}{ }^{-1}, n=4\right)$. A comparison between DIC measurements by the two methods is shown in Fig. 6. The average relative difference between these two methods was $0.3 \%$, equivalent to about $\pm 6 \mu \mathrm{mol} \mathrm{kg}{ }^{-1}$ for typical seawater DIC concentrations. This value is 2-3 times higher than the precision of either method, though still reasonably low, and is only a little larger than the recommended target ( $\pm 4 \mu \mathrm{mol} \mathrm{kg}^{-1}$; Dickson et al., 2007) for between-cruise and between-laboratory bias of DIC coulometric measurements.

\subsubsection{Total alkalinity}

Samples for total alkalinity were analyzed, either onboard or at IOS, often using the same samples as those analyzed for DIC. Samples were stored at $4{ }^{\circ} \mathrm{C}$ and, unless analyzed within two days of collection, were poisoned with $\mathrm{HgCl}_{2}$. Total alkalinity $\left(A_{\mathrm{T}}\right)$ was determined by software-controlled potentiometric titrations using combination $\mathrm{pH}$ electrodes and dilute hydrochloric acid dispensed by automated burettes. Total alkalinity was determined up to 1999 following the closed-cell method described by Millero et al. (1993), and using open-cell titrations after that date (Fig. 5). Titration endpoints were determined using modified Gran plots (Hansson and Jagner, 1973) until 2008, when a nonlinear least-squares end-point determination (e.g., Dickson et al., 2007) was implemented. The titration data for samples collected during the 


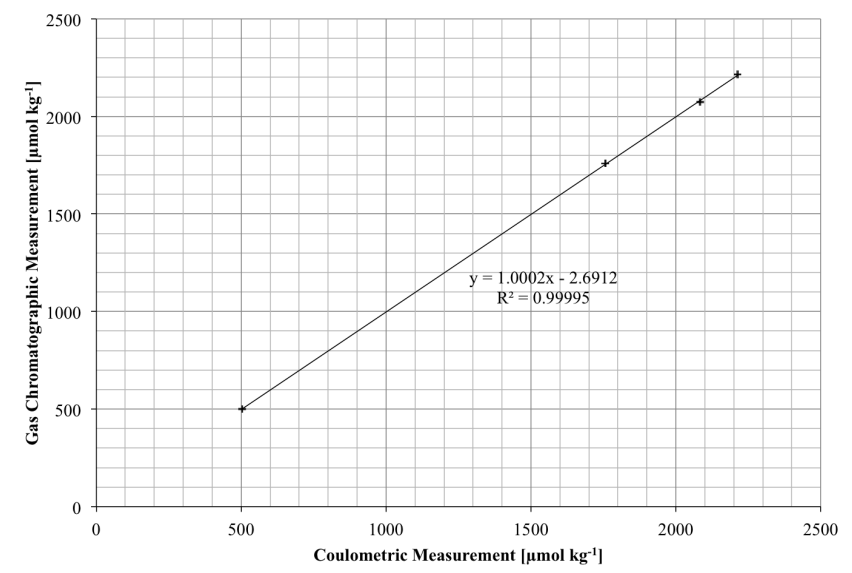

Figure 6. Dissolved inorganic carbon concentrations for samples measured by both gas chromatography and coulometry as part of a method intercomparison study. Line of best fit (equation: $y=$ $1.0002 x-2.6912$ ) is plotted through the samples. Error bars representing the standard deviation of replicate samples (mean GC SD $=2.8 \mu \mathrm{mol} \mathrm{kg}{ }^{-1}$, mean coulometric $\mathrm{SD}=1.8 \mu \mathrm{mol} \mathrm{kg} \mathrm{kg}^{-1}$ ) are smaller than the symbols.

CASES cruises were analyzed with a proprietary algorithm specifically designed for shallow slope end-point detection from the titration curves (see Mucci et al., 2010). Onboard, a constant volume of sample or standard was drawn for analysis using a calibrated, water-jacketed pipet, and the data were

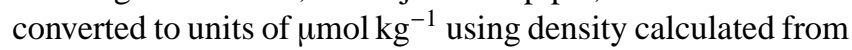
the sample salinity and the analysis temperature. Onshore, samples or standards were weighed prior to analysis. Similar to the DIC coulometric method, daily analyses of certified reference materials (CRMs) provided by Andrew Dickson (Scripps Institute of Oceanography) and IOS-prepared secondary standards calibrated against CRMs were used to assure accuracy. Precision of the alkalinity analyses, based on pooled standard deviations of sample duplicates, has generally been $\pm 2-5 \mu \mathrm{mol} \mathrm{kg}{ }^{-1}$.

A rigorous crossover analysis of alkalinity data from the Pacific (PACIFICA data product, available through the Carbon Dioxide Information and Analysis Center, CDIAC) revealed that alkalinity analyses conducted by closed-cell titrations at IOS during the 1990s were often offset, and usually high, compared to results from other times and other laboratories. It is reasonable to assume that the alkalinity data from before 1999 in the data set reported here may suffer from the same limitations, as the same protocols were used for both data sets. A similar evaluation of this data set is difficult, because of variations in station distributions (Fig. 2b) and a lack of deep-water samples on many cruises. Nevertheless, a plot of the limited alkalinity data from $2500 \mathrm{~m}$ (which roughly coincides with a deep temperature minimum and is slightly deeper than the minimum depth used for secondary quality control crossover analysis in the GLODAP, CARINA and PACIFICA data products; e.g., Tanhua et al., 2010) in the

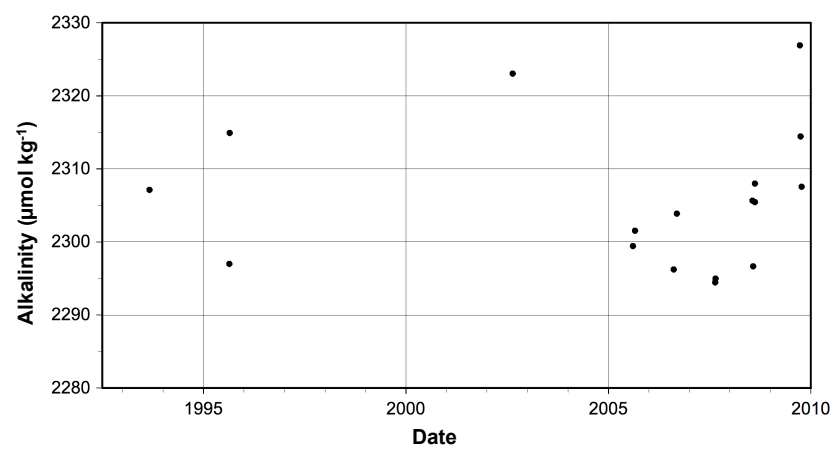

Figure 7. Alkalinity measurements from $2500 \mathrm{~m}$ in the central Canada Basin.

central Canada Basin (Fig. 7) indicates that alkalinity measurements may have been high during the 1993 and 1995 cruises. More importantly, however, the alkalinity values at $2500 \mathrm{~m}$ show high variability, even after 2000 , without any clear offset between individual cruises. Therefore, based on the information available at this time, we can neither rule out nor confidently confirm any analytical bias in the alkalinity measurements between cruises.

\subsection{4 pH}

The only direct $\mathrm{pH}$ measurements included in this data set were from the CASES cruise in 2003-2004. On this cruise, $\mathrm{pH}$ was determined spectrophotometrically on the total proton scale. Details of the sampling and analysis procedures are given by Mucci et al. (2010), which we briefly summarize here. Samples were collected in $125 \mathrm{~mL}$ plastic bottles, leaving as small a headspace as possible. The samples were brought to thermal equilibrium in a constant temperature bath held at $25^{\circ} \mathrm{C}$, and analyzed within $3 \mathrm{~h}$ of collection. The colorimetric analysis was performed using a HewlettPackard $^{\circledR}$ (HP-8453A) UV-visible diode-array spectrophotometer and a $5 \mathrm{~cm}$ quartz cell. Measurements were carried out at the wavelengths of maximum absorbance for the protonated and deprotonated forms of the two indicators used: phenol red (433 and $558 \mathrm{~nm}$ ) and $m$-cresol purple (434 and $578 \mathrm{~nm}$ ). The accuracy of the method was assured using the same procedure to analyze TRIS buffers prepared at salinities of 25 and 35 . Reproducibility of the $\mathrm{pH}$ measurements, based on pooled standard deviations of sample duplicates over the 11-month cruise, was better than $0.005 \mathrm{pH}$ units.

\subsubsection{Quality Control (QC) procedures}

In primary quality control of the database, we paid particular attention to parameters required to calculate the dissolved inorganic carbon system in seawater (DIC, alkalinity, $\mathrm{pH}$, temperature, salinity). The data were assessed to identify outliers and obvious errors. We have not addressed any issues with systematic biases between analyses or cruises 
(secondary QC). In order to identify outliers and errors in the inorganic carbon data, property-property plots were generated for small groupings of stations within a similar sampling area. When outliers or errors were identified, the suspect data point was flagged. In keeping with the flagging schemes of other global data products such as GLODAP (Global Ocean Data Analysis Project) and CARINA (Carbon Dioxide in the Atlantic Ocean), raw data were flagged following the WOCE (World Ocean Circulation Experiment) data flagging scheme. Specifically, integer values of 2 (good), 3 (questionable) and 4 (bad) were used to flag data in the final data set.

We generated DIC-salinity and alkalinity-salinity plots for all cruises. Measurements that were outliers, especially in both the DIC-S and alkalinity-S plots, were flagged as questionable (3) or bad (4), especially if there was a known problem with the sampling or analysis. In general, more variability was allowed for near-surface and upper thermocline values during the flagging process. Near-surface values were almost never flagged as questionable or bad unless there were very obvious errors or unrealistic values. For the most part, we retained the "good" flag (2) for any data points of borderline quality. Other supporting data included in the data set (such as temperature, salinity, oxygen, and dissolved nutrients) had previously undergone primary QC analysis (see Table 1 for references). Nevertheless, this did not necessarily mean the data were flagged, but rather that only the finalized, good quality data were archived. Thus, unless flagged, all of these previously quality-controlled data are assumed to be of good quality.

\section{Summary}

This paper describes the compilation of nearly four decades of dissolved inorganic carbon system measurements in the Canadian Arctic. This data set comprises more than four thousand discrete samples of DIC, alkalinity, and/or pH, and associated physical and biogeochemical parameters (e.g., temperature, salinity, $\mathrm{O}_{2}$, and silicate). Much of the inorganic carbon system data included here had not been previously published, quality checked, or archived prior to this compilation. These data are now available in a compiled form that can be used by the scientific community investigating the global carbon cycle and included in global data products, such as GLODAP.

\section{Data access}

The full database is published at http://cdiac.ornl.gov/ftp/ oceans/IOS_Arctic_Database/.Condensed metadata are contained in the header of the data file. The readme file contains a cruise number-to-EXPOCODE translation table.
Acknowledgements. The compilation of this data set was funded by the Fisheries and Oceans Canada International Governance Strategy, and we are grateful to Paul Lyon for administering those funds. This data set encompasses decades of work conducted by an overwhelming number of people. We thank all of the scientists, technicians, personnel, and crew who were responsible for the collection and analysis of the over 22000 samples included in the final data set. We also thank Gillian Moody and Agneta Fransson for starting this data compilation more than 10 years ago. Figures 1 and 2 were created using Ocean Data View (Schlitzer, R., Ocean Data View, http://odv.awi.de, 2012).

Edited by: D. Carlson

\section{References}

AMAP, AMAP Assessment 2013: Arctic Ocean Acidification. Arctic Monitoring and Assessment Programme (AMAP), Oslo, Norway, viii + 99 pp., 2013.

Anonymous (Ed.): CASES2004, Leg 8 (0405) CCGS Amundsen Cruise \& Preliminary Data Report, Cruise Report, Université Laval, Québec, Canada, 84 pp., 2004.

Byrne, R. H., Kump, L. R., and Cantrell, K. J.: The influence of temperature and $\mathrm{pH}$ on trace metal speciation in seawater, Mar. Chem., 25, 163-181, 1988.

Byrne, R. H., Mecking, S., Feely, R. A., and Liu, X.: Direct observations of basin-wide acidification of the North Pacific Ocean, Geophys. Res. Lett., 37, L02601, doi:10.1029/2009GL040999, 2010.

Carmack, E. C., Macdonald, R. W., O’Brien, M., Pearson, R., Timmermans, L., Sieberg, D., Hardenberg, B. V., Sutherland, N., Tuele, D., Jackson, F., and White, L.: Physical and Chemical Data Collected in the Beaufort Sea and the Canadian Archipelago, August-September 1995, Can. Data Rept. Hydrogr. Ocean. Sci., 147, 281 pp., 1996.

Deming, J. (Ed.): CASES2004, Leg 4 (0401) CCGS Amundsen Cruise Report 7 January to 18 February, Cruise Report, Université Laval, Québec, Canada, 6 pp., 2004a.

Deming, J. (Ed.): CASES2004, Leg 5 (0402) CCGS Amundsen Cruise Report 18 February to 31 March, Cruise Report, Université Laval, Québec, Canada, 67 pp., 2004b.

Dickson, A. G., Sabine, C. L., and Christian, J. R. (Eds.): Guide to best practices for ocean $\mathrm{CO}_{2}$ measurements, PICES Special Publication, 3, 191 pp., 2007.

DOE, Dickson, A. G. and Goyet, C. (Eds.): Handbook of Methods for the Analysis of the Various Parameters of the Carbon Dioxide System in Sea Water, Version 2, ORNL/CDIAC-74, 1994.

Falkner, K. K., Macdonald, R. W., Carmack, E. C., and Weingartner, T.: The potential of barium as a tracer of Arctic water masses, The Polar Oceans and Their Role in Shaping the Global Environment, American Geophysical Union, 63-76, 1994.

Feely, R. A., Doney, S. C., and Cooley, S. R.: Ocean acidification: Present conditions and future changes in a high- $\mathrm{CO}_{2}$ world, Oceanography, 22, 36-47, 2009.

Fortier, M. (Ed.): CASES 2002 cruise report \& preliminary data report, 20 September to 14 October 2002 expedition onboard the CCGS Pierre Radisson, Cruise Report, Université Laval, Québec, Canada, 74 pp., 2002. 
Fortier, L. and Cochran, J. K.: Introduction to special section on Annual Cycles on the Arctic Ocean Shelf, J. Geophys. Res., 113C, C03S00, doi:10.1029/2007JC004457, 2008.

Hansson, I. and Jagner, D.: Evaluation of the accuracy of Gran plots by means of computer calculations, Anal. Chim. Acta, 65, 363373,1973

Hardenberg, B. V. (Ed.): Cruise Report for the Institute of Ocean Sciences Cruise 2000-20 aboard the CCGS Sir Wilfred Laurier, 5 July-5 August 2000, Cruise Report, Fisheries and Oceans Canada, 2000.

Johnson, K. M., King, A. E., and Sieburth, J. McN.: Coulometric $\mathrm{TCO}_{2}$ analysis for marine studies: an introduction, Mar. Chem., 16, 61-82, 1985.

Johnson, K. M., Sieburth, J. McN., Williams, P. J. leB., and Branstrom, L.: Coulometric total carbon dioxide analysis for marine studies: automation and calibration, Mar. Chem., 21, 117133, 1987.

Johnson, K. M., Wills, K. D., Butler, D. B., Johnson, W. K., and Wong, C. S.: Coulometric total carbon dioxide analysis for marine studies: maximizing the performance of an automated gas extraction system and coulometric detector, Mar. Chem. 44, 167187,1993

Macdonald, R. W., Iseki, K., Carmack, E. C., Macdonald, D. M., O'Brien, M. C., and McLaughlin, F. A.: Data Report: NOGAP B.6; Beaufort Sea Oceanography, September, 1986, Can. Data. Rept. Hydrogr. Ocean Sci., 58, 68 pp., 1988a.

Macdonald, R. W., Iseki, K., O'Brien, M. C., McLaughlin, F. A., McCullough, D., Macdonald, D. M., Carmack, E. C., Adams, H., Yunker, M., Miskulinand, G., and Buckingham, S.: NOGAP B.6, Volume 5: Chemical data collected in the Beaufort Sea and Mackenzie River delta, March-July 1987, Can. Data. Rept. Hydrogr. Ocean Sci., 60, 55 pp., 1988b

Macdonald, R. W., Iseki, K., O’Brien, M. C., McLaughlin, F. A., McCullough, D., Macdonald, D. M., Carmack, E. C., Adams, H., Yunker, M., Miskulinand, G., and Buckingham, S.: NOGAP B.6, Volume 4: Chemical data collected in the Beaufort Sea, Summer 1987, Can. Data. Rept. Hydrogr. Ocean Sci., 60, 102 pp., 1988c.

Macdonald, R. W. and Carmack, E. C.: Age of Canada Basin deep waters: a way to estimate primary production for the Arctic Ocean, Science, 254, 1348-1350, 1991.

Macdonald, R. W., Carmack, E. C., McLaughlin, F. A., Sieber, D., O'Brien, M. C., Paton, D., Pearson, R., Yang, L., and Gobeil, C.: Oceanographic Data collected from the Henry Larsen in the Beaufort Sea, August-September 1990, Can. Data. Rept. Hydrogr. Ocean Sci., 97, 151 pp., 1991.

Macdonald, R. W., O’Brien, M., Carmack, E. C., Pearson, R., McLaughlin, F. A., Sieberg, D., Barwell-Clarke, J., Paton, D. W., and Tuele, D.: Physical and Chemical Data Collected in the Beaufort, Chukchi and East Siberian Seas, August-September 1993, Can. Data Rept. Hydrogr. Ocean. Sci., 139, 288 pp., 1995.

McLaughlin, F.: Cruise Report: Scientific Log for the Institute of Ocean Sciences Cruise \#9631 aboard the CCGS Louis S. St. Laurent. 10-24 September 1996, Cruise Report, Fisheries and Oceans Canada, 1996.

McLaughlin, F., Carmack, E. C., O’Brien, M., Adamson, L., Barwell-Clarke, J., Gatien, G., Hingston, M., Johnston, P., May, B., Melling, H., Poliquin, M., Riedel, D., Sieberg, D., Tuele, D., Hardenberg, B. V., Walsh, D., Welch, B., and Welch, C.: Physical and chemical data from the Canadian Arctic Archipelago, Au- gust 28 to 18 September 1997, Can. Data Rept. Hydrogr. Ocean. Sci., 176, 140 pp., 2008.

McLaughlin, F., Carmack, E., O'Brien, M., Gatien, G., Tuele, D., White, L., Moody, G., Balsom, A., and Corkum, M.: Physical and chemical data from the Beaufort Sea and western Canadian Arctic Archipelago, September 2 to 16, 2000, Can. Data Rept. Hydrogr. Ocean. Sci., 180, 167 pp., 2009a.

McLaughlin, F., Carmack, E., O’Brien, M., Barwell-Clarke, J., Gatien, G., Harris, J., Itoh, M., Lichiota, G., Shimada, K., Sieberg, D., Steel, M., Toews, S., Hardenberg, B.V, White, L., Smith, J., Zimmermann, S., and Corkum, M.: Physical and Chemical Data from the Beaufort Sea and Canada Basin, 16 August to 5 September 2002, Can. Data Rept. Hydrogr. Ocean Sci., 181, 223 pp., 2009b.

McLaughlin, F., Carmack, E. C., Hardenberg, B. V., Sieberg, D., Forsland, V., White, L., Richardson, W., and Steel, M.: Physical and chemical data from the Canada Basin, August 2003, Can. Data Rept. Hydrogr. Ocean. Sci., 140, 185 pp., 2009c.

McLaughlin, F., Proshutinsky, A., Carmack, E. C., Shimada, K., Corkum, M., Eert, J., Guay, C., Krishfield, R., Li, B., Maclean, H., Nelson, J., Richardson, W., Sieberg, D., Smith, J., Steel, M., Sutherland, N., Walczowski, W., White, L., Yamamoto-Kawai, M., and Zimmermann, S.: Physical, chemical and zooplankton data from the Canada Basin and Canadian Arctic Archipelago, 29 July to 1 September 2005, Can. Data Rep. Hydrogr. Ocean. Sci., 185: ix + 298 pp., 2010.

McLaughlin, F., Proshutinsky, A., Carmack, E. C., Shimada, K., Brown, K., Corkum, M., Dempsey, M., Drost, H., Eert, J., Green, I., Guay, C., Hutchings, J., Illasiak, J., Jackson, J., Krishfield, R., Li, W. K. W., Maclean, H., Nelson, J., Newhall, K., Nishino, S., Ostrom, W., Smith, J., Steel, M., Sutherland, N., White, L., Yamamoto-Kawai, M., Zhao, J, and Zimmermann, S.: Physical, chemical and zooplankton data from the Canada Basin and Canadian Arctic Archipelago, 20 July to 14 September 2006, Can. Data Rep. Hydrogr. Ocean. Sci., 186: x + 373 pp., 2012.

Miller, L. (Ed.): CASES2003, Leg 2 (0304) CCGS Amundsen Cruise Report, 16 October to 26 November, Cruise Report, Université Laval, Québec, Canada, 85 pp., 2003.

Millero, F. J., Zhang, J.-Z., Lee, K., and Campbell, D. M.: Titration alkalinity of seawater, Mar. Chem., 44, 153-165, 1993.

Mucci, A., Lansard, B., Miller, L. A., and Papakyriakou, T. N.: $\mathrm{CO}_{2}$ fluxes across the air-sea interface in the southeastern Beaufort Sea: Ice-free period, J. Geophys. Res., 115, C04003, doi:10.1029/2009JC005330, 2010.

Nozais, C.: CASES2003, Leg 3 (0305) CCGS Amundsen Cruise \& Preliminary Data Report, 26 November 2003 to 6 January 2004, Cruise Report, Université Laval, Québec, Canada, 36 pp., 2003.

Olsen, A., Key, R. M., Tanhua, T., Hoppema, M., Lauvset, S., Kozyr, A., Steinfeldt, R., Jeansson, E., Pfeil B., and Ishii, M.: Moving from GLODAP, CARINA and PACIFICA to the Global Ocean Data Analysis v.2, GLODAP v2, Climate Change in high Latitudes, Bjerknes Centre 10-years Anniversary Conference, Bergen, Norway, 3 September 2012-6 September 2012, 2012.

Pearson, R., O’Brien, M., Sieberg, D., McLaughlin, F. A., Paton, D. W., Tuele, D., Barwell-Clark, J., Carmack, E. C., Macdonald, R. W., and Galbraith, M.: NOGAP B.6, Physical and Chemical Data collected in the Beaufort Sea and Mackenzie River Delta, April-May and September, 1992, and Ice Core Data collected in 
1991-1992, Can. Data Rept. Hydrogr. Ocean Sci., 129, 199 pp., 1994.

Raven, J. A. and Falkowski, P. G.: Oceanic sinks for atmospheric $\mathrm{CO}_{2}$, Plant Cell Environ., 22, 741-755, 1999.

Sabine, C., Feely, R., Gruber, N., Key, R., and Lee, K.: The Oceanic Sink for Anthropogenic $\mathrm{CO}_{2}$, Science, 305, 367-371, 2004.

Swinnerton, J. W., Linnenbom, V. J., and Cheek, C. H.: Determination of dissolved gases in aqueous solutions by gas chromatography, Anal. Chem., 34, 483-485, 1962.

Tanhua, T., van Heuven, S., Key, R. M., Velo, A., Olsen, A., and Schirnick, C.: Quality control procedures and methods of the CARINA database, Earth Syst. Sci. Data, 2, 35-49, doi:10.5194/essd-2-35-2010, 2010.

Vagle, S. (Ed.): Canada's Three Oceans (C3O) 2008-02 Cruise Report: Report on the Oceanographic Research Conducted aboard the CCGS Sir Wilfred Laurier, 2-29 July 2008, Cruise Report, Institute of Ocean Sciences, Sidney, Canada, 2008.

Vagle, S. (Ed): Canada's Three Oceans (C3O) 2009-06 Cruise Report: Report on the Oceanographic Research Conducted aboard the CCGS Sir Wilfred Laurier, 10-22 July 2009, Cruise Report, Institute of Ocean Sciences, Sidney, Canada, 2009.

Weiss, R. F. and Craig, H.: Precise shipboard determination of dissolved nitrogen, oxygen, argon, and total inorganic carbon by gas chromatography, Deep-Sea Res., 20, 291-303, 1973.

Wong, C. S.: Quantitative analysis of total carbon dioxide in sea water: A new extraction method, Deep-Sea Res., 17, 9-17, 1970.
Wong, C. S., Cretney, W. J., Christensen, P., and MacDonald, R. W.: Hydrocarbon Levels in the Marine Environment of the Southern Beaufort Sea, Beaufort Sea Project Technical Report, 38, 113 pp., 1976.

Zimmermann, S. (Ed.): Canada's Three Oceans (C3O) 2007-19 Cruise Report: Report on the Oceanographic Research Conducted aboard the CCGS Louis S St. Laurent, 4-26 July 2007, Cruise Report, Institute of Ocean Sciences, Sidney, Canada, 2007.

Zimmermann, S. and McLaughlin, F. (Eds.): Joint Ocean Ice Study (JOIS) 2009 Cruise Report: Report on the Oceanographic Research Conducted aboard the CCGS Louis S. St.-Laurent, 17 September to 15 October 2009, Cruise Report, Institute of Ocean Sciences, Sidney, Canada, 54 pp., 2009.

Zimmermann, S., Eert, J., and McLaughlin, F. (Eds.): Joint Ocean Ice Study (JOIS) 2007 Cruise Report: Report on the Oceanographic Research Conducted aboard the CCGS Louis S. St. Laurent, 26 July to 31 August 2007, Cruise Report, Institute of Ocean Sciences, Sidney, Canada, 39 pp., 2007.

Zimmermann, S., Kawai, M., and McLaughlin, F. (Eds.): Joint Ocean Ice Study (JOIS) 2008 Cruise Report: Report on the Oceanographic Research Conducted aboard the CCGS Louis S St. Laurent, 17 July to 21 August 2008, Cruise Report, Institute of Ocean Sciences, Sidney, Canada, 57 pp., 2008. 


\section{Appendix A}

\section{Sample collection methods}

This appendix is a transcription of the printed instructions used by IOS for collecting inorganic carbon samples before 1994, when the first manual of standard methods for seawater inorganic carbon system measurements was published (DOE, 1994). The protocols reproduced here are largely consistent with those in the DOE manual.

\section{A1 Instructions for taking alkalinity, total $\mathrm{CO}_{2}$ and seawater $\mathrm{C}-13$ samples}

\section{A1.1 Description}

These water samples are to determine the concentration of oceanic carbon dioxide. Samples are to be collected by a seawater loop or by a Niskin bottle, and are to be stored in 500-mL Pyrex bottles with the addition of a little powdered mercuric chloride as preservative and refrigerated at about $4{ }^{\circ} \mathrm{C}$.

\section{A1.2 Sources of error}

Carbon dioxide is given off by smoke stacks, people, gasoline engines, birds and decaying organic matter, etc. A sample of water would change its carbon dioxide content very rapidly if exposed to these obvious sources. Avoid prolonged exposure of the sample of water. Try to finish the sampling, addition of mercuric chloride, and replacement of the greased stopper all within $10 \mathrm{~min}$. The equatorial waters contain much higher carbon dioxide than the air, and will lose the gas very rapidly. Success of sampling depends on immediate filling up of the bottle from the bucket.

Sunlight and heat cause decomposition of the grease and of the sample. The bottles should be kept refrigerated at about $4{ }^{\circ} \mathrm{C}$.

It is most important to add the mercuric chloride, which retards any bacterial action before laboratory analysis. Always check again that mercuric chloride has indeed been added. Since we are looking for sources of high carbon dioxide in surface water, a single sample without preservative can jeopardize our conclusions.

\section{A1.3 Choosing a place to sample}

A sample uncontaminated by oil, sewage discharge, or excessive agitation is desirable. An ideal time to sample will be the period 09:00 to 12:00 local time. It is convenient to get ready just before arriving at a station.

\section{A1.4 Taking the sample}

The bottles provided have been thoroughly cleaned and dried. It is unnecessary to rinse the bottle since agitation is a source of error. Slowly draw the seawater into the bottle with the end of the tubing touching the bottom of the bottle. When the bottle is full, allow the seawater to overflow for at least half the volume of the bottle. Replace the stopper on the full bottle. Set the bottle on a secure table-top. Remove the stopper and dry it with pieces of lint-free absorbing paper. Apply four parallel strips of grease on the stopper. Pour off about $5-\mathrm{mL}$ of seawater to leave an air space just below the ground glass neck, which is then dried with lint-free absorbing paper.

Invert the vial of mercuric chloride so that crystals of mercuric chloride fall straight into the seawater in the bottle without touching the ground glass neck. Wipe off any mercuric chloride accidentally adhered to the neck with a piece of lintfree absorbing paper. Drop the greased stopper straight back into the ground glass neck and give the stopper a vertical push to squeeze out the air between the grease strips. Wrap PVC tape around the bottle with tangential forces applied at the stopper to prevent loosening of the stopper. If you are not sure mercuric chloride has been added, dump in another vial of mercuric chloride as described above.

\section{A1.5 Recording of data}

As a reminder that mercuric chloride has indeed been added, please write down " $\mathrm{HgCl}_{2}$ added" on the label right after you invert the vial.

Record on the label the following:

1. $\mathrm{HgCl}_{2}$ added

2. Bottle Number

3. Cruise Number

4. Station Number

Record in the log the following:

1. Bottle Number

2. Date and Time

3. Cruise Number

Salinity, temperature and oxygen data are also required. Put the bottle back in the box.

\section{A1.6 Storage}

Immediate refrigeration is required. Samples may be stored in a lab refrigerator, then transferred in a case to a ship's cold storage. Storage temperature should be about $4^{\circ} \mathrm{C}$. 


\section{A1.7 Caution}

Mercuric chloride is a poison. Keep the vial away from coffee or food. Wash hands thoroughly before eating or smoking. In case of accidental swallowing, induce vomiting (if the patient is still conscious) by giving him a tablespoonful of salt in a glass of warm water and repeat until vomit fluid is clear.

Give milk or whites of eggs beaten with water.

Keep patient warm and quiet.

Do not breathe dust of mercuric chloride. Avoid contact with eyes or prolonged contact with skin. 